\title{
Studies on unidentified growth factors
}

\author{
2.* Progressin, a growth factor for chicks
}

\author{
By J. BUNYAN, ELSPETH A. MURRELL, M. A. CAWTHORNE \\ AND B. T. REDMAN
}
Beecham Research Laboratories, Nutritional Research Centre, Walton Oaks, Tadworth, Surrey

(Received 8 March 1973-Accepted 24 fuly 1973)

\begin{abstract}
1. Chicks at ro $\mathrm{d}$ of age were given diets containing all the nutrients known to be required, with L-amino acids in place of protein. Dietary supplements were added isonitrogenously.

2. Ox liver (roo g/kg) greatly improved the chicks' growth rate, whereas torula yeast $(5 \circ \mathrm{g} / \mathrm{kg})$ was inactive. The activity of fresh moist liver was considered to be due largely to an organic factor, because of the inactivity of water and the low activity of liver ash.

3. The growth rates of chicks receiving diets based upon casein and isolated soya-bean protein were significantly improved by the inclusion of $100 \mathrm{~g}$ fresh ox liver $/ \mathrm{kg}$, but not of $50 \mathrm{~g}$ torula yeast $/ \mathrm{kg}$.

4. These results show that chicks receiving an amino acid diet require an organic growth factor (Progressin) that differs from the yeast factor required by rats receiving an amino acid diet.
\end{abstract}

In the previous paper (Bunyan, Murrell, Cawthorne \& Redman, 1974), we confirmed the discovery by Schwarz, Smith \& Oda (1966, 1967) and Schwarz (1970) of an unidentified natural factor, factor $G$, that increased the growth rate of rats receiving an amino acid diet.

We have found evidence for the existence of a different growth factor for chicks receiving an amino acid diet. We wish to call this chick growth factor Progressin.

\section{EXPERIMENTAL}

\section{Experimental diets and ingredients}

The composition of the basal amino acid diet is given in Table $\mathrm{r}$. The composition of the amino acid mixture was that found by Dean \& Scott (1965) to be optimal for chicks, but we decreased the total amount in the diet from $229.3 \mathrm{~g} / \mathrm{kg}$ to $179.8 \mathrm{~g} / \mathrm{kg}$.

Additions to the basal diet were made at the expense of glucose. When adding torula yeast, ox liver or dried distillers' solubles to the diet, the total amino acid composition of the diet was kept constant by omitting from the basal amino acid mixture amounts of amino acids equivalent to those contained in the additives. Bunyan et al. (1974) have given the amino acid analysis of torula yeast and ox liver. For dried distillers' solubles the analysis given by Block \& Weiss (1956) was used. Nitrogen contents of diets and additives were determined by the Kjeldahl method. The ash fraction of liver was obtained by heating it to $520^{\circ}$ for $\mathrm{I} 8 \mathrm{~h}$ in a muffle furnace.

\footnotetext{
* Paper no. 1: Br. J. Nutr. (1974), 31, 167.
} 


\section{Table I. Composition of basal amino acid diet}

Ingredient

Amino acid mixture*

Maize oil

Salt mixturef

Vitamin mixturef

Cellophane flakes

Glucose
Dietary concentration $(\mathrm{g} / \mathrm{kg})$

$$
\begin{array}{r}
\times 79.8 \\
\times 50.0 \\
67: 5 \\
7.2 \\
30.0 \\
565.5
\end{array}
$$

* Amino acids were obtained from Deutsche Ajinomoto GmbH, Hamburg, Germany; Cambrian Chemicals Ltd, Croydon, and Sigma Chemical Co., London. The amino acid mixture contained (L-forms, except glycine; g/kg diet): arginine hydrochloride $8 \cdot 6$, histidine hydrochloride $\mathrm{H}_{2} \mathrm{O} 2 \cdot 4$, isoleucine 6.3 , leucine $9 \cdot 4$, lysine hydrochloride 8.8 , methionine 3.5 , cystine $2 \cdot 7$, phenylalanine $5 \cdot 3$, tyrosine $4 \cdot 9$, threonine $5 \cdot 1$, tryptophan $\mathrm{I} \cdot 8$, valine $6 \cdot 4$, glutamic acid 94 , glycine $12 \cdot 6$, and proline $7 \cdot 9$. + Contained (g/kg diet): $\mathrm{CaCO}_{3} 22 \cdot 78, \mathrm{~K}_{2} \mathrm{HPO}_{4} 9 \cdot 4, \mathrm{NaH}_{2} \mathrm{PO}_{4} \cdot 2 \mathrm{H}_{2} \mathrm{O} 7 \cdot 63, \mathrm{CaH}_{4}\left(\mathrm{PO}_{4}\right)_{2} \cdot 2 \mathrm{H}_{2} \mathrm{O}_{4} \cdot 6$, $\mathrm{NaCl} \mathrm{g} \cdot 2, \mathrm{MgSO}_{4} \cdot \mathrm{H}_{2} \mathrm{O}_{2} \cdot 93$, ferric citrate $0.42, \mathrm{MnSO}_{4} \cdot 4 \mathrm{H}_{2} \mathrm{O} 0.44, \mathrm{KI} 0.04, \mathrm{ZnCO}_{3} 0 \cdot 02, \mathrm{CuSO}_{4} \cdot 5 \mathrm{H}_{2} \mathrm{O}$ $0.02, \mathrm{CoCl}_{2} .6 \mathrm{H}_{2} \mathrm{O} 0.004$ and $\mathrm{Na}_{2} \mathrm{SeO}_{3} 0.00033$.

I Contained $(\mathrm{mg} / \mathrm{kg}$ diet): choline chloride 2200 , thiamin 8.8 , riboflavin 8.8 , calcium pantothenate 22, nicotinic acid I Io, pyridoxine 8.8 , biotin 0.3 , pteroylmonoglutamic acid $3 \cdot 3$, menaphthone sodium bisulphite $I \cdot I$, cyanocobalamin $0.02, D-\alpha$-tocopheryl acetate 70 and also, in gelatin-coated beadlets, $8.9 \mathrm{mg}$ retinyl acetate and $\mathrm{i}$ ro $\mu \mathrm{g}$ cholecalciferol.

Table 2. Compositions of casein and soya-bean protein diets $(\mathrm{g} / \mathrm{kg})$

$\begin{array}{lcc}\text { Ingredient } & \text { Casein diet } & \begin{array}{c}\text { Soya-bean } \\ \text { protein diet }\end{array} \\ \text { Casein* } & 163 \cdot 0 & - \\ \text { Soya-bean protein } \dagger & - & 183 \cdot 0 \\ \text { L-Arginine hydrochloride } & 3 \cdot 3 & - \\ \text { L-Cystine } & 1 \cdot 5 & 1 \cdot 7 \\ \text { Glycine } & 2 \cdot 5 & 1 \cdot 4 \\ \text { L-Methionine } & - & 1 \cdot 9 \\ \text { Maize oil } & 100 \cdot 0 & 100 \cdot 0 \\ \text { Salt mixturet } & 67 \cdot 5 & 67 \cdot 5 \\ \text { Vitamin mixturef } & 7 \cdot 2 & 7 \cdot 2 \\ \text { Cellophane flakes } & 30 \cdot 0 & 30 \cdot 0 \\ \text { Glucose } & 625 \cdot 0 & 607 \cdot 3\end{array}$

* 'Low vitamin content'; Fisons Ltd, Loughborough.

+ Skidmore Enterprises, Cincinatti, USA.

+ See Table 1 .

The diets based on casein and isolated soya-bean are given in Table 2. Torula yeast $(5 \circ \mathrm{g} / \mathrm{kg})$ and ox liver $(100 \mathrm{~g} / \mathrm{kg})$ were added to these diets at the expense of glucose and either casein or isolated soya-bean protein. The amino acid supplements were also changed (see Table 4) so that the total amino acid composition of the diets remained the same. Supplements of methionine, cystine and glycine were added to the soya-bean protein diets in order to bring the total concentrations to those recommended by the (US) National Research Council (I960). Arginine and glycine were added to the casein diets for the same reason, but cystine was supplemented to only $60 \%$ of the requirement because of the excess methionine present. Other amino acids were found to be above the recommended levels. 
Table 3. Growth-promoting activity of torula yeast, ox liver and other materials for chicks receiving an amino acid diet

\begin{tabular}{|c|c|c|}
\hline \multirow[b]{2}{*}{ Addition to basal diet $\uparrow(\mathrm{g} / \mathrm{kg})$} & \multicolumn{2}{|c|}{ Growth rate $(\mathrm{g} / \mathrm{d})$} \\
\hline & Expt I & Expt 2 \\
\hline $\begin{array}{l}\text { None } \\
\text { Ox livert, roo } \\
\text { Liver ash, } 2 \\
\text { Salt mixture } \$ \text { equivalent to the minerals of torula yeast, } 2 \cdot 4 \\
\text { Torula yeast } \mid \text {, 50 } \\
\text { Salt mixture } \$ \text { equivalent to the minerals of torula yeast, } 5.6 \\
\text { Deionized water, } 70\end{array}$ & $\begin{array}{l}6 \cdot 04 \\
8 \cdot 85^{* *} \\
6 \cdot 76^{*} \\
6 \cdot 18 \\
5 \cdot 87 \\
6 \cdot 65 \\
6 \cdot 46\end{array}$ & $\begin{array}{l}4 \cdot 22 \\
6 \cdot 14 * * * \\
4 \cdot 13 \\
4 \cdot 31 \\
3 \cdot 87 \\
4 \cdot 57 \\
4 \cdot 09\end{array}$ \\
\hline SE of treatment means & 0.23 & 0.23 \\
\hline
\end{tabular}

Significantly greater than control value: $P<0.05$; $* * P<0.01$; *** $P<0.001$.

+ See Table I for composition of the basal diet and p. 179 for details of dietary adjustments.

I Obtained from a local butcher.

$\$$ Bunyan et al. (1974).

II Lake States Yeast \& Chemical Division of St Regis Paper Co., Rhinelander, Wisconsin.

\section{Experiments}

Day-old male chicks, Warren sex-linked Rhode Island hybrids, were purchased from Southdown Hatcheries, Uckfield, Sussex, and reared in electrically heated wirefloored cages. Food and water were always freely available. For the first 7 -1o d, the chicks were given a conventional diet and then weighed. The required number of chicks was then selected from the middle range of body-weights and divided at random into groups of eight or ten. Four cages of eight chicks or three cages of ten (see below) were allocated to each experimental diet, one of which was always the unsupplemented basal diet. A partly randomized cage design was used. The chicks were weighed individually at the beginning and end of the feeding period of 8-10 d. Food consumption was measured in some experiments.

\section{Statistical interpretation of the results}

The results were analysed, separating the variance between groups treated alike from the variance within groups. When the between-groups variance was significant, it was used to provide an estimate of error. However, in most experiments it was not significant and it was therefore pooled with the within-groups variance to provide the estimate of error variance. The significance of treatment effects were assessed by the method of least significant differences. Any individual weight gain more than 2 SD above or below the mean for the group of chicks treated alike was replaced by the mean value for the remainder and the total number of degrees of freedom was decreased by one.

\section{RESULTS}

As shown in Table 3, torula yeast did not improve the growth rate of chicks receiving the amino acid diet. In a preliminary experiment, not shown, dried brewers' yeast also failed to improve growth on the amino acid diet. However, ox liver induced 
Table 4. Expt 3. Growth promoting-activity of torula yeast and ox liver for chicks receiving diets containing protein

(Each diet was given to four groups of eight chicks; mean results with their standard errors are given)

\begin{tabular}{|c|c|c|c|c|}
\hline $\begin{array}{l}\text { Group } \\
\text { no. }\end{array}$ & $\begin{array}{l}\text { constituents } \\
\text { of diet }{ }^{+} \\
(\mathrm{g} / \mathrm{kg})\end{array}$ & $\begin{array}{l}\text { L-Amino acid } \\
\text { supplements } \\
(g / \mathrm{kg})\end{array}$ & $\begin{array}{l}\text { Growth rate } \\
(\mathrm{g} / \mathrm{d})\end{array}$ & $\begin{array}{l}\text { Gain:feed } \\
\quad \text { ratio }\end{array}$ \\
\hline $\mathrm{I}$ & Casein 163 & $\begin{array}{l}\text { Arg hydrochloride } \\
3 \cdot 3 \text {, cys } 1 \cdot 5 \text {, gly } 2-5\end{array}$ & $7 \cdot 2$ & 0.37 \\
\hline 2 & $\begin{array}{l}\text { Casein } \mathrm{r} 35, \\
\text { torula yeast } 5^{\circ}\end{array}$ & $\begin{array}{l}\text { Arg hydrochloride } \\
3 \cdot 1 \text {, cys I } 9 \text {, gly } 2 \cdot 1\end{array}$ & $7 \cdot 4$ & $0.40 t$ \\
\hline 3 & $\begin{array}{l}\text { Casein } 144, \\
\text { ox liver } 100\end{array}$ & $\begin{array}{l}\text { Arg hydrochloride } \\
2 \cdot 7 \text {, cys } 1 \cdot 4 \text {, gly } 1.8\end{array}$ & $8 \cdot z^{*}$ & $0: 39$ \\
\hline 4 & $\begin{array}{l}\text { Soya-bean } \\
\text { protein } 183\end{array}$ & $\begin{array}{l}\text { Met } r \cdot 9 \text {, cys } 1 \cdot 7 \text {, } \\
\text { gly } \mathrm{I} \cdot 4\end{array}$ & II 1 & 0.517 \\
\hline 5 & $\begin{array}{l}\text { Soya-bean } \\
\text { protein } \mathbf{I}_{5} \mathbf{I}, \\
\text { torula yeast } 50\end{array}$ & $\begin{array}{l}\text { Met } I \cdot 8 \text {, cys } I \cdot 6 \text {, } \\
\text { gly } I \cdot 2\end{array}$ & $10 \cdot I$ & 0.49 \\
\hline 6 & $\begin{array}{l}\text { Soya-bean } \\
\text { protein } 160, \\
\text { ox liver } 100\end{array}$ & $\begin{array}{l}\text { Met } 1.5 \text {, cys } 1 \cdot 6 \text {, } \\
\text { gly } 0.8\end{array}$ & $12 \cdot 6 * * *$ & 0.49 \\
\hline \multicolumn{2}{|c|}{ SE of treatment means } & & 0.29 & $\begin{array}{l}\text { O.0IO (4 results) } \\
\text { 0.0II (3 results) }\end{array}$ \\
\hline
\end{tabular}

* Significantly greater than group I result $(P<0.05)$.

*** Significantly greater than group 4 result $(P<0.001)$.

+ See Table 2 for other ingredients and p. 18 o for details of dietary adjustments.

$\mp$ One discordant value has been omitted.

Table 5. Growth-promoting activity of dried distillers' solubles and various phenolic acid mixtures for chicks receiving an amino acid diet

(In each experiment, each diet was given to three groups of ten chicks; mean results with their standard errors are given)

Addition to basal diet $\dagger$

None

Dried distillers' solubles $(5 \circ \mathrm{g} / \mathrm{kg})$

Phenolic acid mixturet

no. 1

no. 2

no. 3

no. 4

SE of treatment means

\begin{tabular}{cccc}
\multicolumn{4}{c}{ Growth rate $(\mathrm{g} / \mathrm{d})$} \\
\hline Expt 4 & Expt 5 & Expt 6 & Expt 7 \\
4.44 & 4.69 & 4.71 & 4.79 \\
4.83 & 3.93 & 4.38 & - \\
4.78 & 4.63 & - & - \\
$5.40^{*}$ & 4.50 & 5.21 & - \\
- & - & -7.90 & 4.90 \\
- & - & 4.80 & - \\
0.28 & 0.31 & 0.24 & 0.23
\end{tabular}

* Significantly greater than controls $(P<0.05)$.

+ See Table $I$ for composition of the basal diet and p. I79 for details of dietary adjustments.

$\ddagger$ See Table 6 for composition. 
Table 6. Composition of phenolic acid mixtures $\mathrm{I}-4$

\begin{tabular}{|c|c|c|c|c|}
\hline \multirow[b]{2}{*}{ Ingredient } & \multicolumn{4}{|c|}{ Dictary concentration $(\mathrm{mg} / \mathrm{kg})$} \\
\hline & $I^{*}$ & $2 \uparrow$ & 3 & 4 \\
\hline 2-Hydroxybenzoic acid & - & Io & 30 & - \\
\hline 3-Hydroxybenzoic acid & 54 & - & - & - \\
\hline 4-Hydroxybenzoic acid & 24 & - & - & - \\
\hline 2,5-Dihydroxybenzoic acid & - & 10 & 30 & - \\
\hline 2,6-Dihydroxybenzoic acid & - & 10 & 30 & Io \\
\hline 3,5-Dihydroxybenzoic acid & - & Io & 30 & 10 \\
\hline 2,3-Dihydroxybenzoic acid & - & - & 30 & - \\
\hline 3,4-Dihydroxybenzoic acid & I6 & - & 30 & - \\
\hline 4-Hydroxy-3,5-dimethoxybenzoic acid & - & Io & - & - \\
\hline 4-Hydroxy-3-methoxybenzoic acid & $3^{8}$ & - & 30 & - \\
\hline 2-Hydroxycinnamic acid & - & Io & 30 & - \\
\hline 4-Hydroxycinnamic acid & I4 & ro & 30 & - \\
\hline 3,4-Dihydroxycinnamic acid & 28 & - & - & - \\
\hline 4-Hydroxy-3-methoxycinnamic acid & 26 & - & 30 & - \\
\hline 2-Hydroxyphenylacetic acid & - & Io & $3^{\circ}$ & Io \\
\hline 4-Hydroxyphenylacetic acid & - & I0 & 30 & Io \\
\hline
\end{tabular}

* The same as mixture no. I of Dixon \& Couch (1970), but it was used at the higher of their two dietary levels.

$\uparrow$ The same as mixture no. 2 of Dixon \& Couch (1970).

large growth increments. In view of the moist nature of the ox liver and the growth stimulus produced by adding water to the amino acid diet for rats (Bunyan $e t a l$. I974), a moist diet was tried for chicks. As shown in Table 3, the $70 \mathrm{~g} / \mathrm{kg}$ supplement of water did not stimulate growth.

Liver ash gave a small, significant response in one experiment, but not in the other. A salt mixture equivalent to liver minerals and also one equivalent to torula yeast minerals were both ineffective.

These findings lead to the conclusion that the growth-promoting agent in liver is largely organic in nature.

The growth-promoting activity of ox liver for chicks was also evident when the liver was added to diets based upon casein or isolated soya-bean protein (Table 4). The response of $14 \%$ on both diets was much less than that obtained with the amino acid diet. With these diets, as with the amino acid diet, the supplement of torula yeast failed to improve growth.

Dixon \& Couch (1970) identified nine phenolic acids as being responsible for the unidentified growth factor (UGF) activity of dried distillers' solubles. As shown in Table 5, this material proved inactive under the conditions of the assay. None of the phenolic acid mixtures stimulated growth, apart from mixture no. 2 which gave a positive response in Expt 4 but not in Expts 5 and 6.

\section{DISCUSSION}

Various liver and yeast preparations have been reported to be sources of UGF for chicks (Menge, Denton, Sizemore, Lillie \& Bird, 1953; Dam, Morrison \& Norris, 1959; Couch \& Stelzner, 1961). Although, in agreement with these authors, we did 
find that ox liver improved the growth rate of chicks receiving a protein-containing diet, we found no activity for torula yeast, in contrast to the report of Menge et al. (I953).

Amino acid diets have been used in studies of the growth factor activities for poultry of fish solubles and maize fermentation condensed solubles (Bhargava \& Sunde, I969), fishery products (Miller \& Soares, 1972) and soya-bean meal (Young, Blair \& Scott, I97 I). However, yeasts and liver do not seem to have been studied in this way. Using an amino acid diet, we found that neither torula yeast nor dried brewers' yeast stimulated growth in chicks, whereas ox liver did. Bunyan et al. (r974) have previously shown that, whereas both of these yeasts contain an organic factor for rats receiving an amino acid diet, ox liver does not. These findings, therefore, distinguish the organic factor in liver (Progressin) that stimulates growth in chicks from the organic factor in yeast (factor $G$ ) that stimulates growth in rats.

Although the growth response to liver was very much greater with an amino acid diet than with a protein-containing diet, it is possible that both responses are due to the same factor, which may be identical with one of the UGF reported by others. Factor $\mathrm{G}$ in yeast may also be identical with a factor reported previously.

The present authors hope to report fractionation studies on natural sources of Progressin, in due course.

We thank Dr J. Green for his advice and encouragement, and Mr D. Hiley, Miss R. J. Castle and Mrs J. Townsend for technical assistance.

\section{REFERENCES}

Bhargava, K. K. \& Sunde, M. L. (1969). Poult. Sci. 48, 694 .

Block, R. J. \& Weiss, K. W. (1956). Amino Acid Handbook p. 296. Springfield, Illinois: Charles C. Thomas.

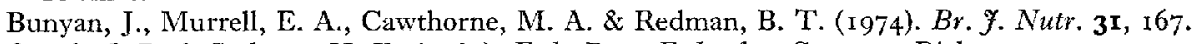

Couch, J. R. \& Stelzner, H. D. (196r). Fedn Proc. Fedn Am. Socs exp. Biol. 20, 370.

Dam, R., Morrison, A. B. \& Norris, L. C. (1959). F. Nutr. 69, 277.

Dean, W. F. \& Scott, H. M. (1965). Poult. Sci. 44, 803 .

Dixon, T. \& Couch, J. R. (1970). Poult. Sci. 49, 393.

Menge, H., Denton, C. A., Sizemore, J. R., Lillie, R. J. \& Bird, H. R. (I953). Poult. Sci. $32,863$.

Miller, D. \& Soares, J. H. Jr (1972). Poult. Sci. 5r, 1.288.

National Research Council (1960). Publs natn. Res. Coun., Wash. no. 827.

Schwarz, K. (1970). F. Nutr. 100, 1487.

Schwarz, K., Smith, J. C. \& Oda, T. A. (rg66). Fedn Proc. Fedn Am. Socs exp. Biol. 25, 542 Abs.

Schwarz, K., Smith, J. C. \& Oda, T. A. (1967). Lancet i, 73 r.

Young, R. J., Blair, R. \& Scott, M. L. (r97I). Fedn Proc. Fedn Am. Socs exp. Biol. 30, 64I Abs. 